\title{
Clinical Features of Lewis-Sumner Syndrome: Can Trauma Precipitate Symptoms?
}

\author{
Isaac Michael William Hughes, Alan Edward Goodridge
}

\begin{abstract}
Introduction: Lewis-Sumner syndrome (LSS) is a demyelinating peripheral neuropathy described in 1982. Methods: We reviewed the charts of nine LSS patients in neurological care for their symptoms, response to different treatment regimens, and pattern of nerve involvement. Results: One patient had an Adie's pupil. Every patient studied had median nerve involvement. Seven of nine patients required intravenous immunoglobulin (IVIg) therapy and all showed improvement with IVIg. Four of nine patients received oral steroid therapy and had some improvement. Two of nine patients received azathioprine to little effect. Two of nine patients experienced significant trauma while receiving neurological follow-up and their symptoms worsened to a clinically significant degree afterward. Discussion: We noticed a possible association between trauma and symptom severity in cases of LSS with preexisting neurological follow-up. We hypothesize that physical trauma exacerbates LSS. To our knowledge, this is an unreported phenomenon.
\end{abstract}

RÉSUMÉ: Est-il possible qu'un traumatisme déclenche l'apparition de symptômes liés au syndrome de Lewis-Sumner? Introduction: Le syndrome de Lewis-Sumner (SLS) est une neuropathie périphérique démyélinisante qui a été décrite en 1982. Méthodes: Nous avons passé en revue les dossiers de 9 patients atteints du SLS et bénéficiant de soins neurologiques visant à soulager leurs symptômes. Nous nous sommes aussi penchés sur leurs réponses à divers régimes de traitement et sur les niveaux d'atteinte de la conduction nerveuse. Résultats: Si l'ensemble des patients ont vu leur nerf médian être atteint, mentionnons qu'un seul d'entre eux a été atteint de pupille tonique d'Adie. Soulignons aussi que sept patients ont eu besoin d'une thérapie d'immunoglobulines administrées par voie intraveineuse (IgIV). Tous ont alors montré des signes d'amélioration. Quatre patients sur neuf se sont vu administrer des stéroïdes par voie orale. On a alors noté chez eux une certaine amélioration. Deux patients ont également bénéficié d'azathioprine, ce qui a entraîné peu d'effet chez eux. Enfin, deux autres patients ont subi de graves traumatismes durant leur période de suivi neurologique. D'un point de vue clinique, leurs symptômes se sont par la suite aggravés de manière notable. Discussion: Nous avons ainsi observé un lien potentiel entre des traumatismes et la gravité des symptômes de patients atteints du SLS bénéficiant d'un suivi neurologique. Nous émettons l'hypothèse que les traumatismes physiques peuvent exacerber les manifestations du SLS, ce qui, à notre connaissance, constitue un phénomène clinique n'ayant jamais été signalé.

Keywords: CIDP, Trauma, MADSAM, Neuropathy, Peripheral neuropathy, Lewis-Sumner, Carpal tunnel syndrome

doi:10.1017/cjn.2018.389

Can J Neurol Sci. 2019; 46: 243-247

\section{INTRODUCTION}

Autoimmune disorders are a common source of illness and are often of uncertain origin. The focus of this article is a variant of chronic immune demyelinating polyradiculoneuropathy (CIDP) known as multifocal acquired demyelinating sensory and motor neuropathy (MADSAM) or Lewis-Sumner syndrome (LSS). First described by Lewis et al. ${ }^{1}$ LSS is estimated to account for $16 \%-18 \%$ of CIDP. ${ }^{2,3}$ It typically presents in the upper limbs and can have either sensory or motor components, such as pain or weakness in discrete areas predicated by peripheral nerve territories. Effective treatments include intravenous immunoglobulin (IVIg), plasmapheresis, and, to an extent, steroids.

The literature on this condition is relatively sparse, many reports being of small patient populations. Another contributing factor to our gap in knowledge is that most of these case studies are limited in detail. Rayjaballi et al. wrote a detailed review of eight cases and reviewed another 82 reported cases that were of pure upper limb onset. ${ }^{4}$ However, they were hampered by a lack of available detail and had to include a category for those in whom information was inadequate. Although a review in 2007 by Lewis found over 100 cases of LSS, this is an inadequate sample size for proper scientific inquiry. ${ }^{5}$

Diagnostic delay in LSS has the potential for significant ramifications. It has variable presentations so is likely to be missed, which could explain the small number of cases reported in the literature. We have encountered two cases with closely followed symptoms that worsened to a clinically significant degree after a documented trauma. Finally, we discuss what methods we have found to be effective in achieving good symptomatic control and remission in our patient population.

From the Department of Medicine, Division of Neurology, Dalhousie University, Halifax, Nova Scotia, Canada (IMWH); Department of Neurology, Memorial University of Newfoundland, St. John's, Newfoundland, Canada (AEG)

Received September 19, 2017. Final Revisions Submitted November 20, 2018. Date of Acceptance December 11, 2018.

Correspondence to: Isaac Michael William Hughes, Department of Medicine, Division of Neurology, Dalhousie University, 222-2080 Quingate Place, Halifax, NS, Canada B3L 4R9. Email: mwihughes@gmail.com 
Table 1: The sex, onset characteristics, progression, nerve involvement, and requirement of treatment for nine patients with LSS

\begin{tabular}{|c|c|c|c|c|c|c|c|c|c|}
\hline Patient & Sex & $\begin{array}{c}\text { Upper/lower } \\
\text { limb onset }\end{array}$ & $\begin{array}{c}\text { Progression to } \\
\text { upper } \\
\text { and lower limb } \\
\text { involvement? } \\
\end{array}$ & \begin{tabular}{|c} 
Nerves \\
documented \\
to be involveda
\end{tabular} & \begin{tabular}{|c}
$\begin{array}{c}\text { Nerve(s) with } \\
\text { conduction } \\
\text { block }\end{array}$ \\
\end{tabular} & $\begin{array}{c}\begin{array}{c}\text { Sensory or } \\
\text { motor } \\
\text { symptom onset }\end{array} \\
\end{array}$ & $\begin{array}{c}\begin{array}{c}\text { Sensorimotor } \\
\text { involvement }\end{array} \\
\end{array}$ & $\begin{array}{c}\text { Concomitant } \\
\text { disease/cranial } \\
\text { nerve } \\
\text { involvement } \\
\end{array}$ & $\begin{array}{c}\text { Effective } \\
\text { treatment } \\
\text { modalitiesb }\end{array}$ \\
\hline 1 & $\mathrm{M}$ & Upper & Yes & $\begin{array}{l}\text { Median } \\
\text { Ulnar Peroneal } \\
\text { Tibial } \\
\text { Sural }\end{array}$ & $\begin{array}{l}\text { Median } \\
\text { Ulnar } \\
\text { Tibial }\end{array}$ & Motor & Sensorimotor & N/A & IVIg \\
\hline 2 & M & Upper & Yes & \begin{tabular}{|l} 
Median \\
Ulnar \\
Peroneal
\end{tabular} & Median & Sensory & Sensorimotor & N/A & IVIg \\
\hline 3 & $\mathrm{~F}$ & Mixed & Yes & \begin{tabular}{|l} 
Median \\
Ulnar \\
Peroneal \\
Sural \\
Tibial \\
\end{tabular} & Median & Sensorimotor & Sensorimotor & N/A & $\begin{array}{l}\text { IVIg } \\
\text { Steroid }\end{array}$ \\
\hline 4 & $\mathrm{M}$ & Upper & No & \begin{tabular}{|l} 
Median \\
Ulnar \\
Peroneal \\
Sural
\end{tabular} & $\begin{array}{l}\text { Median } \\
\text { Ulnar }\end{array}$ & Sensory & Pure sensory & N/A & IVIg \\
\hline 5 & M & Lower & Yes & \begin{tabular}{|l} 
Median \\
Ulnar \\
Radial \\
Peroneal \\
Sural \\
Median \\
Ulnar \\
Radial \\
Tibial
\end{tabular} & $\begin{array}{l}\text { Peroneal } \\
\text { Ulnar }\end{array}$ & Sensory & Sensorimotor & N/A & $\begin{array}{c}\text { IVIg } \\
\text { Steroid } \\
\text { Azathioprine }\end{array}$ \\
\hline 6 & $\mathrm{M}$ & Upper & No & & Median & Sensory & Pure sensory & N/A & N/A \\
\hline 7 & $\mathrm{~F}$ & Upper & No & \begin{tabular}{|l} 
Median \\
Ulnar
\end{tabular} & Median & Sensory & Sensorimotor & N/A & N/A \\
\hline 8 & $\mathrm{M}$ & Upper & Yes & \begin{tabular}{|l|} 
Median \\
Ulnar \\
Radial \\
Peroneal \\
Sural \\
Tibial \\
\end{tabular} & $\begin{array}{l}\text { Median } \\
\text { Ulnar }\end{array}$ & Motor & Sensorimotor & Adie's pupil & $\begin{array}{c}\text { IVIg } \\
\text { Steroid } \\
\text { Azathioprine }\end{array}$ \\
\hline 9 & M & Lower & Yes & \begin{tabular}{|l} 
Median \\
Ulnar \\
Radial \\
Peroneal \\
Sural \\
Tibial
\end{tabular} & $\begin{array}{l}\text { Median } \\
\text { Ulnar } \\
\text { Tibial }\end{array}$ & Motor & Sensorimotor & N/A & IVIg \\
\hline
\end{tabular}

IVIg, intravenous immunoglobulin; LSS, Lewis-Sumner syndrome; N/A, not applicable.

${ }^{a}$ Involved nerves includes any clinically significant electrophysiological deficit.

${ }^{\mathrm{b}}$ Effective treatment defined as arresting the progression of symptoms, clinical improvement, or electrophysiological improvement.

\section{Methods}

This project followed the guidelines set out by the Memorial University of Newfoundland Human Research Ethics Association for a case series. Patients with a diagnosis of LSS were identified by Neurologists at the Health Sciences Center, St. John's Newfoundland. The patients' charts were then requisitioned and kept in a locked archive room to maintain strict confidentiality. Each patient was assigned a designation that all information gathered were documented under for their clinical presentation and laboratory study results.

For inclusion into the study, the patients needed to meet diagnostic criteria as per guidelines defined by the
European Federation of Neurological Societies/Peripheral Nerve Society. ${ }^{6}$

We recorded the patients' electrodiagnostic findings upon their first presentation to our clinic and gathered their history and physical information in detail where available. The course of the subjects' illness and response to treatment were then documented and summarized.

\section{Results}

The key clinical and electrophysiological elements for all nine patients can be found in Table 1 . Seven of the nine patients were male. The age of onset ranged from 33 to 64 years. 
Table 2: Electrodiagnostic findings of Patient 1 on first presentation to our clinic

\begin{tabular}{|c|c|c|c|c|c|c|c|c|c|c|}
\hline \multirow[b]{2}{*}{ Nerve } & \multirow[b]{2}{*}{ Stimulus } & \multirow[b]{2}{*}{ Recording } & \multicolumn{2}{|c|}{ Latency (ms) } & \multicolumn{2}{|c|}{ Distance (mm) } & \multicolumn{2}{|c|}{ Velocity (m/s) } & \multicolumn{2}{|c|}{ Amplitude (mV) } \\
\hline & & & Left & Right & Left & Right & Left & Right & Left & Right \\
\hline Peroneal & Ankle & EDB & NR & NR & NR & NR & $\mathrm{NR}$ & NR & $\mathrm{NR}$ & NR \\
\hline \multirow[t]{2}{*}{ Tibial } & Ankle & \multirow[t]{2}{*}{$\mathrm{AH}$} & 7.08 & 5.83 & & & N/A & N/A & 0.37 & 0.44 \\
\hline & Pop. Fos & & 21.17 & 18.42 & 340 & 345 & 24.1 & 27.4 & 0.19 & 0.19 \\
\hline \multirow[t]{5}{*}{ Ulnar } & Wrist & \multirow[t]{5}{*}{ ADM } & 3.58 & 3.33 & & & N/A & N/A & 5.83 & 4.76 \\
\hline & B. elbow & & 7.75 & 7.08 & 220 & 210 & 52.8 & $\mathrm{e}$ & 4.15 & 3.01 \\
\hline & A. elbow & & 9.33 & 8.50 & 90 & 90 & 56.8 & 63.5 & 4.13 & 2.59 \\
\hline & Axilla & & 11.33 & 11.25 & 140 & 145 & 70.0 & 52.7 & 3.92 & \\
\hline & Erb's & & 15.75 & 15.83 & & & & & 3.2 & 1.38 \\
\hline \multirow[t]{5}{*}{ Median } & Wrist & \multirow[t]{3}{*}{ APB } & 7.5 & 3.5 & & & & & 0.56 & 2.22 \\
\hline & Elbow & & 12.83 & 8.42 & 220 & 220 & 41.2 & 44.7 & 0,54 & 1.79 \\
\hline & Erb's & & 20.42 & 16.00 & & & & & 0.31 & 1.09 \\
\hline & Index & \multirow[t]{2}{*}{ Wrist } & 3.47 & & 140 & & 40.4 & & 2.48 & \\
\hline & Palm & & 1.93 & & 85 & & 44.0 & & 4.19 & \\
\hline Ulnar & Palm & Wrist & 1.65 & & 90 & & 54.5 & & 2.67 & \\
\hline Radial & Forearm & $R$ thumb & 1.72 & & 115 & & 67.0 & & 3.03 & \\
\hline Sural & Mid-calf & Ankle & 3.42 & & 140 & & 41.0 & & 0.23 & \\
\hline
\end{tabular}

ADM, abductor digiti minimi; AH, abductor hallucis; APB, abductor pollicis brevis; EDB, extensor digitorum brevis; NR, non-reactive.

Clinical symptoms at first presentation were confined to the arms in six patients and to the legs in two. Symptoms affected at least one arm and one leg in one patient at presentation. Symptoms progressed to involve both arms and legs in three patients with initial arm involvement, and in two patients with initial leg involvement, giving a total of six patients with both arm and leg involvement.

At onset, symptoms were purely motor in three patients, purely sensory in five and sensorimotor in one. Six progressed to manifest sensorimotor findings; three from pure motor and three from pure sensory initial presentations.

Treatment was required for eight of the nine patients, who received at least one infusion of IVIg and four of them also received oral prednisone. Of the seven patients who received IVIg, two became dependent on continuous infusions, the remainder tapered off of IVIg therapy successfully.

One patient was tested for anti-GM1 and found to be negative. Conduction block in sensory nerves was defined by either temporal dispersion of the response or a large drop in amplitude. In two of our cases, some significant physical trauma was temporally associated with an exacerbation of the symptoms of LSS, as follows:

\section{Patient 1}

A 33-year-old male presented in 2007 with upper- and lowerlimb weakness and patchy sensory loss. A diagnosis of hereditary motor sensory neuropathy had been made elsewhere, despite the absence of any family history of that condition and negative genetic testing. He had previously presented in 1995 with weakness in his right hand progressing to involve his right foot by 2000 . His symptoms were clinically stable until 2005 when he was involved in a severe motor vehicle accident (MVA) which caused a cervical acceleration injury and post-traumatic stress disorder. Three days after which he experienced worsening pain in his right hand. Within 1 month, there was objective wasting of intrinsic muscles of his right hand.

The initial wasting and weakness of the muscles in his right hand increased after the MVA and he began to experience significant pain in both of his hands, requiring narcotic analgesia. He was also found to have mild weakness in his limb girdles and moderate to severe weakness in his distal limb muscles. Electrodiagnostic studies showed conduction block in both his right and left ulnar nerves. Further electrodiagnostic results can be found in Table 2.

He also complained of loss of sensation in the feet with a substantial weakness of the ankle dorsiflexors and a steppage gait such that he required several breaks to walk $500 \mathrm{~m}$. The ankle reflexes were absent. Conduction block was later detected in both right and left tibial nerves, left median, and left ulnar nerves. Peroneal motor responses were absent. Neither right nor left peroneal sensory potentials could be recorded.

The asymmetrical sensorimotor involvement with persistent conduction block led to a diagnosis of LSS and IVIg treatment was instituted with monthly infusions over the following 5 years. Sensation returned in his legs although pinprick sensation in his feet only later returned to normal. Almost all measures of power increased significantly, typically by at least one point on the Medical Research Council scale over the next year.

The patient has remained neurologically stable without monthly infusions of IVIg, although there remains significant weakness bilaterally in his median-nerve innervated muscles and a foot slap in his gait for which orthotics are still required. Because of the reduction in pain, he has now ceased taking narcotic analgesics.

\section{Patient 8}

This 62-year-old male presented in 2002 with upper limb sensorimotor symptoms and an Adie's pupil. Initially, he had 
Table 3: Electrodiagnostic findings of Patient 8 on first presentation to our clinic

\begin{tabular}{|c|c|c|c|c|c|c|c|c|c|c|}
\hline \multirow[b]{2}{*}{ Nerve } & \multirow[b]{2}{*}{ Stimulus } & \multirow[b]{2}{*}{ Recording } & \multicolumn{2}{|c|}{ Latency (ms) } & \multicolumn{2}{|c|}{ Distance $(\mathbf{m m})$} & \multicolumn{2}{|c|}{ Velocity $(\mathbf{m} / \mathbf{s})$} & \multicolumn{2}{|c|}{ Amplitude (mV) } \\
\hline & & & Left & Right & Left & Right & Left & Right & Left & Right \\
\hline \multirow[t]{4}{*}{ Median } & D2 & Wrist & & 2.8 & & 130 & & 46 & & 4.2 \\
\hline & Wrist & APB & & 3.9 & & & & & & 6.4 \\
\hline & Elbow & Wrist & & 8.7 & & 225 & & 47 & & 6.3 \\
\hline & F wave & & & 35.2 & & & & & & \\
\hline \multirow[t]{4}{*}{ Ulnar } & D5 & Wrist & & NR & & & & & & \\
\hline & Wrist & \multirow[t]{3}{*}{ ADM } & & 4.3 & & & & & & 3.9 \\
\hline & B. elbow & & & 8.8 & & 190 & & 42 & & 3.1 \\
\hline & A. elbow & & & 12.8 & & 130 & & 33 & & 2.9 \\
\hline Radial & Arm & D1 & & 3.7 & & 145 & & 53 & & 3.6 \\
\hline Peroneal & Calf & Ankle & & NR & & $\mathrm{NR}$ & & NR & & NR \\
\hline Sural & Calf & Ankle & & NR & & NR & & NR & & NR \\
\hline
\end{tabular}

D1, first digit; D2, second digit; D5, fifth digit; ADM, abductor digiti minimi; APB, abductor pollicis brevis; NR, non-reactive.

reported mild, bilateral wasting of the intrinsic muscles of his hands and marked bilateral wasting of the intrinsic muscles of his feet. Electrodiagnostic studies showed absent right ulnar sensory, right peroneal sensory, and right sural sensory nerve potentials. Further electrodiagnostic information can be found in Table 3. Anti-GM1 antibody studies were negative. He remained stable until 2006 when he underwent several consecutive back surgeries. In the weeks following the last of these surgeries, he experienced worsening pain in his right foot and new pain in his entire left leg below the knee which was previously absent. This contributed to a fall that led to a hairline fracture in his foot. His upper limb examination at this time was unremarkable. Follow-up electrodiagnostic studies at this time showed new findings in that the right and left peroneal, left tibial motor, right sural sensory and left sural sensory responses were unobtainable.

He was suspected of having LSS and made a good recovery from his symptoms only after starting a regime of prednisone, azathioprine, and IVIG. Neither his Adie's pupil nor his sensory symptoms fully remitted. He still has some loss of pinprick and light touch sensation in his distal lower limbs. His most recent nerve conduction studies showed unobtainable right peroneal, right tibial, left ulnar sensory, right ulnar sensory, and right sural sensory nerve potentials.

\section{Discussion}

The most striking finding in our study population was the temporal association between a physically traumatic event and worsening of the disease. Out of nine patients, there were two who had experienced an exacerbation of symptoms after being exposed to significant trauma. Critically, the exposure to trauma and ensuing worsening of disease process occurred after the patient was already subject to close neurological follow-up. This mitigates the chances of a selection bias, where the illness was already present and was only discovered because a trauma had brought the patient to the hospital. Such events support the hypothesis that trauma may play a role in the autoimmune aspect of the disease. It would be difficult to organize a study with enough power to prove an absolute link between the two given the relative rarity of people involved in traumas who also have an established diagnosis of LSS or other CIDP. However, a similar relationship between trauma and neurologic inflammation is seen in other peripheral nerve conditions.

There is an established link between stress and autoimmune disorders of many different systems. ${ }^{7-14}$ Although, there are many neurological conditions documented to be triggered or exacerbated by trauma, to our knowledge, this link has not been demonstrated in LSS. An association between surgical intervention and inflammatory nerve injury has, similarly, emerged. Staff et al. described a series of 21 patients who experienced post-operative inflammatory neuropathies. ${ }^{15}$ Critically, it did not appear to matter what surgical procedure their patients received, and that they improved on steroid and/or IVIg. More recently, Freo et al. describe the case of a post-operative brachial plexopathy that had objective findings on physical exam and EMG which only improved after administration of IVIg after failing steroids and neuropathic pain agents. ${ }^{16}$ Further similarities are reflected in the clinical course of brachial plexitis also known as ParsonageTurner syndrome (PTS). Unlike in our cases, there is no disease present until after an insult to the body has occurred. However, the relationship between physical trauma and inflammation of the nerves is well documented in PTS. Furthermore, as in our cases of LSS, new cases of PTS have been triggered by a variety of inciting events such as burns, surgery, infection, and endurance exercise. ${ }^{17-20}$ These cases draw many parallels with our own experience, especially that of treating Patient 8 who experienced LSS exacerbation after repeated surgical intervention.

Because of a missed diagnosis, one patient became addicted to the narcotic analgesics that had been used to ease his chronic pain. The damage done here was twofold. The diagnostic delay precluded appropriate treatment so the disease could progress unimpeded; the patient became addicted to narcotic medication, an affliction that had serious ramifications to his personal life. Furthermore, chronic opioid usage has been shown to increase natural cytotoxicity ${ }^{21}$ and interacts with the HypothalamusPituitary-Adrenal (HPA) axis as well as the regulation of 
lymphocyte and natural killer cell production. ${ }^{22}$ This may have contributed to this patient's disease process.

\section{Effective Treatment}

Among our nine cases, seven required treatment. The factor that consistently led to positive outcomes for them was access to IVIg therapy. We found IVIg to be superior to prednisone in terms of effectiveness and side effect profile which is in keeping with the literature. ${ }^{2}$ Four of nine patients required indefinite treatment to prevent exacerbations; this is known to happen in some cases. ${ }^{4,23}$ Azathioprine was used with little effect in two patients. Limited effectiveness of steroid-sparing agents is prevalent in the literature on LSS and CIDP ${ }^{2,23-25}$ but it is not shown that they perform better than placebo level in a randomized control trial. In some cases where patients with CIDP had been noted to improve while taking azathioprine, they were either taking concomitant steroids or only experienced mild amelioration of some symptoms but with exacerbations of others. ${ }^{26}$ While this is not a recommendation against the use of azathioprine, it would be prudent to reserve the use of this agent as an option when other treatments are ineffective or not tolerated.

\section{LIMITATIONS}

Because this study represents a chart review, there are some gaps present in the patients' histories. Furthermore, when nerve conduction studies were being performed, research was not the primary aim. It is possible that electrodiagnostic findings among our patients could have been more extensive than what was recorded in the EMG laboratory. Many of the patients' charts are from a time when anti-GM1 testing was not available at our institution. To repeat the testing now would not be practical and so it is not available data for many of our patients.

\section{ACKNOWLEDGMents}

The authors are grateful to Dr. William Pryse-Phillips for providing mentorship throughout the project and Dr. Mark Stefanelli for contributing available cases of LSS. We would also like to acknowledge the late Dr. Richard Marceau for helping to procure funding without which this project may not have been completed. We would also like to thank Ms. Charlene Bowder and Mrs. Patricia Kelly for their administrative assistance and the Seeds, Bridging, and Multidisciplinary fund for supporting the project financially.

\section{Statement of Authorship}

Isaac Hughes was involved in conception of the work, data collection, data analysis and interpretation, drafting the article, critical revisions of the article, and final approval of the version to be published.

Alan Goodridge was involved in the conception of the work, data analysis and interpretation, critical revisions of the article, and final approval of the version to be published.

\section{Disclosures}

Isaac Hughes was employed by Alan Goodridge and paid with funding provided by the Seeds, Bridging, and Multidisciplinary fund at Memorial University of Newfoundland. Otherwise, neither author has any conflict of interest to disclose.

\section{REFERENCES}

1. Lewis RA, Sumner AJ, Brown MJ, Asbury AK. Multifocal demyelinating neuropathy with persistent conduction block. Neurology. 1982;32:958-8.

2. Viala K, Renie L, Maisonobe T, et al. Follow-up study and response to treatment in 23 patients with Lewis-Sumner syndrome. Brain. 2004;127:2010-7.

3. Gorson KC, Ropper AH, Weinberg DH. Upper limb predominant, multifocal chronic inflammatory demyelinating polyneuropathy. Muscle Nerve. 1999;22:758-65.

4. Rajabally YA, Chavada G. Lewis-Sumner syndrome of pure upperlimb onset: diagnostic, prognostic, and therapeutic features. Muscle Nerve. 2009;39:206-20.

5. Lewis RA. Neuropathies associated with conduction block. Curr Opin Neurol. 2007;20:525-30.

6. Van den Bergh PY, Hadden Rd, Bouche P, et al. European federation of neurological societies/peripheral nerve society guideline on management of chronic inflammatory demyelinating polyradiculoneuropathy: report of a joint task force of the European federation of neurological societies and the peripheral nerve society - first revision. Eur J Neurol. 2010;17(3):356-63.

7. Stojanovich L, Marisavljevich D. Stress as a trigger of autoimmune disease. Autoimmun Rev. 2008;7:209-13.

8. Hashizume H, Horibe T, Ohshima A, Ito T, Yagi H, Takigawa M. Anxiety accelerates T-helper 2-tilted immune responses in patients with atopic dermatitis. Br J Dermatol. 2005;152:1161-4.

9. Al'Abadie MS, Kent GG, Gawkrodger DJ. The relationship between stress and the onset and exacerbation of psoriasis and other skin conditions. Br J Dermatol. 1994;130:199-203.

10. Griffiths CEM, Richards HL. Psychological influences in psoriasis. Clin Exp Dermatol. 2001;26:338-42.

11. Herrmann M, Schölmerich J, Straub RH. Stress and rheumatic diseases. Rheum Dis Clin North Am. 2000;26:737-63.

12. Wolfe F. Psychological distress and rheumatic disease: editorial review. Scand J Rheumatol. 1999;28:131-6.

13. Feinstein A, Magalhaes S, Richard JF, Audet B, Moore C. The link between multiple sclerosis and depression. Nat Rev Neurol. 2014;10:507-17.

14. Kuwabara S, Uzawa A, Mori M. Neuroimmunology of a natural disaster. J Neurol Neurosurg Psychiatry. 2017;88:283-4.

15. Staff NP, Engelstad J, Klein CJ, et al. Post-surgical inflammatory neuropathy. Brain. 2010;133:2866-80.

16. Freo U, Zara G, Furnari M, Ori C. Postoperative brachial plexopathy in a diabetic patient. Pain Med. 2016;17:1962-5.

17. Zhao JC, Xian CJ, Yu JA. Parsonage-Turner syndrome in seconddegree contact burns. J Burn Care Res. 2014;34(4):276-80.

18. Verhasselt S, Schelfaut S, Bataillie F, Moke L. Postsurgical Parsonage-Turner syndrome: a challenging diagnosis. Acta Orthop Belg. 2013;79(1):20-4.

19. Schmitt M, Daubail B, Bohm A. Parsonage-Turner syndrome secondary to Lyme disease. Joint Bone Spine. 2018;85(3):387-8.

20. Weng M, Fidel C. Isolated unilateral brachial neuritis of the phrenic nerve (Parsonage-Turner syndrome) in a marathon runner with exertional dyspnea. Sports Health. 2010;2(4):307-10.

21. Jonsdottir IH. Exercise immunology: neuroendocrine regulation of NK-cells. Int J Sports Med. 2000;21:20-3.

22. Hall DM, Suo JL, Weber RJ. Opioid mediated effects on the immune system: sympathetic nervous system involvement. J Neuroimmunol. 1998;83:29-35.

23. Attarian S, Verschueren A, Franques J, Salort-Campana E, Jouve E, Pouget J. Response to treatment in patients with Lewis-Sumner syndrome. Muscle Nerve. 2011;44:179-84.

24. Dyck PJ, O'Brien P, Swanson C, Low P, Daube J. Combined azathioprine and prednisone in chronic inflammatory-demyelinating polyneuropathy. Neurology. 1985;35:1173-6.

25. Sederholm BH. Treatment of chronic immune-mediated neuropathies: chronic inflammatory demyelinating polyradiculoneuropathy, multifocal motor neuropathy, and the Lewis-Sumner Syndrome. Semin Neurol. 2010;30:443-56.

26. Thomas PK, Walker WH, Rudge P, et al. Chronic demyelinating peripheral neuropathy associated with multifocal central nervous system demyelination. Brain. 1987;110:53-76. 